\title{
Karya Klasik Tentang Negara dan Revolusi
}

\author{
Oleh : Mukmin Zaky dan Sobirin
}

\author{
Judul : NEGARA DAN REVOLUSI SOSIAL \\ (PERANCIS, RUSIA, CINA) \\ Penulis : Theda Scocpol \\ Penerbit : Erlangga, Jakarta, 1991 \\ Tebal : xll + 356 Halaman.
}

Semasa mahasiswa, Theda Scocpol adalah mahasiswa kritis sekaligus demonstran konsisten, tidak banyak barangkali mahasiswa yang demikian. Ditahun 1960-an ia selalu terlibat dalam berbagai demonstrasi persamaan hak bagi kulit hitam, juga campur tangan Amerika Serikat di Vietnam, dan lainlain. Baginya dengan perjuangan yang dipilih itu akan semakin mempertajam kesadaran politiknya. Di lain pihak ia juga menjadikan berbagai hal pilihan itu sebagai suatu 'wawasan' untuk kemudian mengoreksinya ulang disaat lain. Itu semua yang menjadikannya berniat serius untuk mengkaji kembali atas tinjauan dan orientasi lama dalam mengembangkan ilmu-ilmu sosial dan sejarah.

Tema-tema kapitalisme, imperialisme, masyarakat petani dan gerakan protes petani, revolusi dan perjuangan kelas model Marxis menjadi perhatiannya. Fokus ini dianalisisnya secara amat kritis sekaligus teoritis.

Buku ini memang bukan karya yang mengikuti alur jaman, melainkan suatu study komprehensip sosiologis historis yang menjelaskan tentang sebab-sebab, kelangsungan revolusi dan hasil-hasil revolusi Perancis 178701800 , revolusi Rusia 191701921 dan revolusi Cina (Tiongkok) 1911-1949. Agaknya sungguh jarang karya semacam ini lahir dan langsung disebut-sebut sebagai sebuah karya klasik dibidangnya. Itu pula keistimewaan buku ini.

Scocpol, yang juga istri seorang dokter peneliti itu, sepenuhnya mémpersiapkan bahan-bahan karyanya ini dari kepustakaan. Karena itu, hal yang baru dalam buku ini justru bukan pada pendekatan 'persepsi' pendataannya, melainkan metode pendekatan masalah yang dipilihnya. Yang khas dalam tipe sosiologis-historisnya ialah orientasinya yang sangat menjurus pada masalah pokok (problem oriented), penggunaan perspektif teoritis yang tegas dan sekaligus konsekwen dalam upayanya menyajikan penjelasan atas deskripsi datanya.

\section{Teori dan Pendekatan}

Bab pertama buku ini dibuka dengan penjelasan gejala revolusi sosial, dimana 
Scocpol mengelaborasi singkat tentang teoriteori makro sosiologis yang ada, kemudian mengungkapkan perspektifnya sendiri.

Ketika mengelaborasi teori makro sosiologis tersebut ia membagi menjadi empat teori besar : 1 . berbagai teori marxis, 2. teori psikologi massa, 3, teori-teori sistem dan nilai dan 4. teori-teori konflik politik. Barangkali berkat ketekunannya dalam mendalami berbagai teori dan sejarah berbagai revolusi itulah yang membuatnya berkesimpulan bahwa semua teori itu ia anggap memadai.

Menurutnya ada tiga teori yang harus ditinjau ulang atas teori-teori yang tidak memadai itu. Pertama, si peneliti perlu tegas memandang permasalahan dari sudut yang non voluntaris dan perspektif struktural. Artinya, perlu melihat bahwa proses-proses historis seperti revolusi, tidak mungkin dijelaskan dari sudut tindakan dan motif yang mengarah ke suatu tujuan tertentu dari pihakpihak yang terlibat. Melainkan harus dilihat sebagai jalin-menjalin dari berbagai tindakan itu yang kemudian membawa hasil yang lazimnya berlainan dengan maksud dan rancangan sebelumnya. Dan hasil-hasil ini tidak selalu sesuai dengan kepentingan dari pihak-pihak yang terlibat. Banyak analisis yang justru sebaliknya voluntaris dan diwarnai oleh tujuan rasional dari mereka yang terlibat.

Kedua, dalam analisa perlu menyertakan masalah hubungan internasional secara politik-militer dan ekonomis serta mengkaitkannya didalam konteks sejarah dunia. Selama ini teori-teori revolusi yang ada terlampau memberi porsi di dalam negeri saja.

Dan ketiga, perlu mengenal otonomi potensial dari lembaga negara dalam percaturannya dengan struktur kepentingan sosial ekonomi. Negara (state) dan masyarakat di lain pihak bukanlah dua hal yang sama, tapi juga tak berguna untuk menganggap lembaga negara dan kegiatan pemerintah cuma sebagai cetusan ekspresi dari kekuatan sosial-ekonomi dan kepentingan-kepentingannya.

Tak pelak lagi titik tolak penting ini ditambah beberapa unsur dari teori marxis dan konflik politik, membentuk perspektif Scocpol. Teori marxis yang diacu Scocpol terutama yang berkaitan dengan analisis kelas. Ini meliputi pembagian masyarakat dalam kelas-kelas sosial, pembagian cara pengendalian sarana-sarana produksi .. khususnya pemilikan tanah -- dan cara penghisapan surplus dari produsen langsung dan hubungan serta ketegangan antara kelaskelas utama, ini semua tidak mungkin diabaikan untuk memahami timbulnya situasi revolusioner.

Tapi analisa semacam ini barulah tahap awal, orang perlu mempertanyakan pula dalam kondisi mana lapisan-lapisan bahwa dapat berhasil melawan mereka yang menghisap atau. bagaimana kelas-kelas dominan mampu mengendalikan lapisanlapisan itu ?. Dalam masalah ini teori konflik politik dapat menolong menjelaskan : "berhasil tidaknya suatu tindakan kolektif bergantung pada sistem berorganisasi di satu pihak dan penguasaan atas sarana kekerasan dandaya paksa pada pihak lain."

Meminjam definisi Lenin dan Samuel P. Huntington, Scocpol merumuskan revolusi sosial sebagai, "......... suatu peralihan (transformasi) yang cepat dan mendasar pada lembaga negara dan struktur kelas sosial .... yang disertai dan untuk sebagian dilakukan oleh pemberontak dari bawah yang berorientasi kelas sesama......." (hal 4-5). Dengan penjelasan teori marxis dan ditambah wawasan teoritis yang memadai Scocpol mengajukan permasalahan sebagai berikut : pertama, bagaimana bisa timbul krisis-krisis revolusioner di Perancis di bawah rezim kuno feodal, Rusia dan Cina dibawah kekaisaran ? Kedua, bagaimana krisis-krisis itu berlangsung ? dan ketiga, apa yang terjadi setelah salah satu elite berhasil merebut 
kendali kekuasaan negara. Atau dengan kata lain, apa yang dihasilkan olch berbagai revolusi itu ?. Pertanyaan-pertanyaan inilah yang menggiring Scocpol menyusun disertasinya ini.

\section{Transformasi, Krisis dan Revolusi}

Pada tiap timbulnya krisis revolusioner di Perancis, Rusia dan Cina ditandai olch ciri spesifiknya masing-masing terutama pada aspek historisnya. Namun demikian, berbagai perbedaan kasus ini juga memperlihatkan jalur paralelnya. Scocpol dalam kaitan inj menempatkan gejala-gejala revolusi ini dalam konteks sejarah dunia, yaitu ; transformasi besar selama dua abad lalu, komersialisasi pada skala dunia, perkembangan teknologi dan munculnya institusi (lembaga) negara nasional (nation state) dan perluasan sistem hubungan negara di eropa pada sisi lainnya.

Pada tiga kasus transformasi ini mengakibatkan rezim absolut yang bersangkutan terpaksa menghadapi kemelut persaingan politik militer dan ekonomi yang semakin ketat, yang munculnya dari negerinegeri yang lebih maju. Inggris muncul sebagai kekuatan konkurensi bagi Perancis; Jerman bagi Rusia. Sedangkan Cina terancam oleh kekuatan Barat terutama

$f$ Inggris. Konkurensi terus menerus yang termanifestasikan antara lain berupa peperangan (jajahan) yang membawa kemerosotan pengaruh dalam berbagai lapangan lalu menekan dan memaksa rezimrezim absolut di tiga negara tersebut merombak tatanan intemalnya terutama dalam bidang tata keuangan, upah dan sistem perpajakan.

Namun, perombakan-perombakan ini -terlebih di Cina dan Perancis -- terbentur pada perlawanan dari pihak lapisan para tuan tanah. Mereka ini bertekad mempertahankan status quo kebebasan-kebebasan pajak dain hak sistem pemilikan. Perlu dicatat, dengan upaya mereka ini turut menyulut ke arah jalan revolusi di Perancis tahun 1787-1788. Di Cina gerakan revolusi sejak bangkitnya insiden Sze-Tjuan (1911) : keputusan pemerintah pusat untuk membeli jalan kereta api ditentang oleh kaum GENTRY (penguasa fcodal tuan tanah) yang tclah banyak menanamkan modalnya dalam perkereta-apian itu.

Dapat disimpulkan, salah satu sebab terjadinya krisis revolusi itu terletak pada kelemahan struktur dalam perangkat organisaasi negara absolutis.

Untuk lebih jauh memahami kelemahan struktural ini perlu mengenal dulu persoalan organisasi Iembaga negara, mulai dari pusat sampai ke jajaran paling bawah; juga perlu mengenal dalam hal apa dan scberapa jauh kepentingan pemerintahan maupun ekonomi elite negara sejajar atau bertentangan dengan kepentingan lapisan pemilik lanah. Disini Scocpol secara sangat teliti dan menarik sekali menguraikan tentang berbagai mitos -khususnya yang berasal dari idcologi Leninis tentang revolusi -- yang diungkapkannya secara definitif.

Selain soal ketegangan-ketegangan antar elite negara dan tuan tanah yang dominan, Scocpol juga melihat banyak ketegangan hubungan antara tuan tanah besar dengan para produsen agraris, sebagai sumber utama konflik politik. Hal ini wajar, didalam masyarakat dimana $80 \%$ - $85 \%$ penduduknya terdiri dari petani yang tidak hanya memproduksi untuk kebutuhan sendiri, tapi juga untuk menghasilkan porsi bagi lapisan atas ditambah lagi dengan pemaksaan pajak sebagai sumber utama penghasilan negara. Dalam masyarakat demikian terlihat jelas siapa yang paling banyak menghisap siapa.

Yang menjadi pertanyaan Scocpol dalam kasus ini, cukupkah mengatakan bahwa penghisapan dan kemiskinan akan menghasilkan pemberontakan ?. Scocpol kemudian meminjam teori Eric Wolf dan menjelaskan, mobilitas politik kaum tani 
hanyalah mungkin apabila mereka mempunyai. "internal leverage" (keuntungan situasi dalam lingkungan sendiri) atau "mobilitas keuntungan taktis". Secara kongkrit ini berarti para petani pelosok daerah (terutama jika terintimidasi) harus dapat menghimbau dan bertahan pada lembagalembaga desa yang menjamin solidaritas tertentu dan harus relatif bebas atau leluasa dari pengawasan tuan tanah.

Kondisi dan persyaratan ini terpenuhi di Perancis 1789 dan masa selanjutnya di Rusia 1905 dan 1917. Berkat kondisi-konḍisi spesifik. itu, yang mempan (tangguh) menghadapi represi politik militer dari pusat negara kecuali di Rusia 1905 yang gagal), berkembanglah gerakan-gerakan protes tradisional yang relatif cepat dan makin meluas melawan strata tuan tanah dominan. Maka lengkaplah situasi revolusioner (krisis revolusi); lembaga negara pusat makin lemah, lapisan-lapisan atas terpecah di dalam, sementara militer tak mampu lagi berfungsi dengan baik, pemberontak telah masuk sampai ke desa-desa. Sudah tentu pemberontak di kota juga penting tetapi pemberontak petani juga nelayan kalau ada pada setiap kasus revolusi jauh lebih penting.

Dalam situasi bias ini, kaum elite radikal semakin tampil kedepan meredam kemelut. Yang menyolok pada tiga kasus ini ialah terdapat banyak persamaan pada pimpinan revolusi dalam konteks latar belakang sosial, pendidikan dan orientasi. Kaum radikal di Perancis banyak berasal dari kaum bukan lingkungan pendidikan dan berasal dari daemah. Istilah yang diberikan Scocpol pada mereka ini "kaum elite marginal". Di Rusia dan Cina, pimpinan revolusi juga banyak dari kalangan profesi, terdidik dan berasal dari kerabat keluarga yang dulu dominan berkuasa; pada kasus' Rusia, dari kelas menengah kota, di Cina khususnya dari petani kaya. Pendek kata ternyata tak ada yang berasal dari kaum proletar.

Berakhimya situasi revolusioner bermula dari stabilitas kekuasaan pusat yang baru dimana pembentukan pasukan tentara yang loyal merupakan pendukung utama. Kemudian hubungan kelas sosial di pedesaan berubah, strata dominan telah digantikan oleh hubungan yang lebih adil. Strata dominan telah kehilangan sebagian pengaruh kekuasaannya dan rezim-rezim authoritarian telah digantikan oleh negara praktis tak ada lapangan kehidupan kemasyarakatan yang tak tersentuh dan meninggalkan jejak kemelut revolusi. Namun yang stessing Scocpol kemudian yaitu' munculnya kekuasaankekuasaan negara secara besar-besaran di bawah rezim yang baru. Sarana-sarana perangkat negara makin kuat disentralisasikan dan secara birokratis dinasionalisasikan. Terutama pada kasus Rusia dan Cina dimana elite baru sekaligus bertujuan memodernisasikan suatu ekonomi nasional, gejala yang sama terdapat pula pada negara berkembang dewasa.ini yang tidak mengalami revolusi.

Demikianlah Theda Scocpol telah dengan sabar dan cermat menganalisa tiga kasus revolusi besar yang pernah ada. Buku ini sangat penting dibaca oleh para dosen, intelektual dan mahiasiswa guna memahami berbagai realitas revolusi negara yang pernah ada. Paling tidak interpretasinya yang "memang beda" telah memperkaya khasanah ilmu sosial kita, nah mengapa kita tidak mencoba membandingkannya dengan kondisi sekarang?

(Mukmin Zakie, SH dan Sobirin) 